\title{
THE BOLTON WHITMAN COLLECTION: A BIBLIOGRAPHY
}

\author{
WORKS BYWHITMAN \\ (arranged chronologically)
}

Leaves of Grass. Brooklyn, New York. 1855.

First edition. Quarto; green cloth; title in gilt on backstrip and both covers; decoration in gilt on backstrip, blind tooled on covers; triple-line border in gilt on both covers; gilt edges; marbled end-papers; frontispiece portrait on plain paper. Bears on the title-page an inscription by Whitman: "for Dr. Johnston." Inside front cover is a press cutting (pasted in by W. W. himself) of R. W. Emerson's famous letter to him of the 21 st July, 1855.

Leaves of Grass. Brooklyn, New York. 1856.

Second edition. Thick 16mo; dull green cloth; title in gilt on front cover, blindstamped on back cover, blind-tooling back and front; title, author's name, and quotation from Emerson, in gilt on backstrip. This quotation was used without Emerson's permission. Although the publisher is not stated it was published by Fowler and Wells, and a leaf of their advertisements is found at the end of the volume. Initialled in red pencil by Walt Whitman on the inside front cover, it was given by Mrs. Mary Davis (Whitman's housekeeper) to J. W. Wallace for Dr. Johnston.

Leaves of Grass. Boston: Thayer and Eldridge. 1860-61 [1879].

Spurious issue of third edition of 1860-61. Although it bears the name of Thayer and Eldridge, and the date 1860-61, it was actually published by Richard Worthington of New York in 1879, several pages of his advertisements being included at the end. Worthington printed this edition from the plates of the Thayer and Eldridge edition of 1860-61, after the latter firm's bankruptcy. This copy was presented to Dr. Johnston by Horace L. Traubel with this inscription: "To Dr. J. Johnston in England, Nov. 29 th, 1892, from Horace L. Traubel-over-sea. With reminders of old love and new, of hopes fulfilled and unrealized dreams."

After All, Not To Create Only; recited by Walt Whitman on invitation of Managers American Institute, on opening their 40th Annual Exhibition, New York, noon, September 7, 1871. Boston: Roberts Brothers. 1871.

In later issues of "Leaves of Grass" this appears under the title, "Song of the Exposition."

Democratic Vistas: Memoranda. Washington, D.C. 1871.

Green paper covers. Published in New York by J. S. Redfield.

Note: This bibliography is based on "A Catalogue of Works by and Relating to Walt Whitman in the Reference Library, Bolton," by Harold Hamer, then chief librarian. It was originally published by the Libraries Committee in 1955. Included here are only the rare items and the manuscript archives housed in the collection; the library also has an impressive collection of books about Whitman and books by members of the Bolton group. 
Leaves of Grass: Passage to India. Washington, D.C. 1871.

Green paper covers. Published in New York by J. S. Redfield. Presented to Dr. Johnston by Whitman and inscribed by him: "J. Johnston from Walt Whitman, July 16, '90."

Leaves of Grass: As a Strong Bird on Pinions Free, and Other Poems. Washington, D.C. 1872. Facsimile signature.

Facsimile signature at foot of preliminary poem, "Souvenirs of democracy." This copy was presented to Dr. Johnston and inscribed by Whitman: "J. Johnston, from Walt Whitman, Jul 16, '90."

Leaves of Grass. Author's edition; with portraits from life. Camden, New Jersey. 1876. Autograph. 2 Portraits.

Autograph on title-page. This copy was sent by Walt Whitman through Horace Traubel "for Johnston," in October, 1891. A portion of the yellow paper wrapper in which it was enclosed has been preserved and bears the following in Whitman's handwriting: "Leaves of Grass. Edition 1876, bound in Italian boards and white leather-autograph-two portraits from life- perfect copy- $\$ 5$."

Another copy.

Received from Whitman by Dr. Johnston in October, 1891.

Another copy.

Inscription on flyleaf: "To Fred Wild, with compliments of Thomas B. Harned April 3, '05." "This book was in Walt Whitman's room where he died."

Two Rivulets; including Democratic Vistas, Centennial Songs and Passage to India. Author's edition. Camden, New Jersey. 1876.

The portrait is signed by Whitman. Preserved in the volume is a portion of the wrapper in which it and the companion volume were enclosed, and has on it inscribed by Whitman: "Centennial edition-Two vols.: Leaves of Grass $\mathcal{E}$ Two Rivulets, bound in half leather and Italian card, containing Autograph, Portraits (three from life), Personal Memoranda of the war, 'Democratic Vistas', \&c., \&c." Across one corner he has added: "A Present to Dr. Johnston thro' kindness of J. W. Wallace (f'm America)."

Leaves of Grass. Philadelphia: Rees Welsh and Company. 1882.

Specimen Days and Collect. Glasgow: Wilson and McCormick. 1883.

Leaves of Grass. Glasgow: Wilson and McCormick. 1884.

With a book-marker issued by the Library of William Jewell College containing quotation from Whitman.

Specimen Days in America; revised by the author, with fresh preface and additional note. The Scott Library. London: The Walter Scott Publishing Company. [1887].

Another copy, newly revised by the author, with fresh preface and additional note. The Camelot Series. London: Walter Scott. 1887.

Democratic Vistas, and Other Papers. [Published by arrangement with the author]. The Camelot Series. London: Walter Scott. 1888.

Another copy.

Complete Poems and Prose of Walt Whitman, 1855 . . . 1888; authenticated and personal book (handled by W. W.) ... Portraits from life ... Autograph. 
[Printed by Ferguson Brothers and Company, Philadelphia]. [1888]. Autograph.

Date on backstrip 1888-'9. Publisher and place of publication not stated. Autograph on first page of "Leaves of Grass." Unnumbered copy of the limited edition of six hundred. Presented to Dr. Johnston by Horace Traubel, June, 1894.

November Boughs. Philadelphia: David McKay. 1888.

Another copy. Portrait frontispiece missing. Inscription: "To Fred Wild with compliments of Thomas B. Harned."

November Boughs. Paisley and London: Alexander Gardner. 1889.

With press cutting of poem written by Whitman for Thanksgiving Day. Another copy.

Leaves of Grass; with, Sands at Seventy, and, A Backward Glance o'er Travel'd Roads . . . portraits from life, autograph. Special ed'n. (300 copies only printed- $\$ 5$ each.) [Printed by Ferguson Brothers and Company, Philadelphia]. 1889. Autograph.

Publisher and place of publication not stated. Leather cover made in pocket-book style and inner pocket, marbled end-papers. Autograph on title-page, and an inscription on the fly-leaf by Whitman: "Dr. Johnston in England, from his friend the author in America."

Good-Bye My Fancy: 2d annex to Leaves of Grass. Philadelphia: David McKay. 1891.

\section{Another copy.}

Brown paper covers, no portrait. Sent by Whitman to Dr. Johnston, May, 1891. Another copy. Inscription on fly-leaf: "Fred Wild from his friend the author, Oct. 21, 1891."

Walt Whitman's last. (In Lippincott's Monthly Magazine, Vol. 48. 1891.)

A single-page article by Whitman, later incorporated in "Good-Bye My Fancy." Another copy.

"Have We a National Literature?"

Offprint from The North American Review, March, 1891.

Leaves of Grass; including Sands at Seventy . . . 1st annex, Good-Bye my Fancy ... 2d annex, A Backward Glance O'er Travel'd Roads, and portrait from life ... Philadelphia: David McKay. 1891-2. Facsimile autograph on titlepage.

Generally referred to as the "death-bed" issue, this was the last edition to be revised by Whitman. The author, who was very ill at the time, ordered that 100 copies be hurriedly bound in rough papers for distribution to his intimate friends. On the titlepage of this copy there is an inscription by Whitman: "Dr. J. Johnston, Bolton, England, $\mathrm{f}^{\prime} \mathrm{m}$ the author, with best wishes, remembrance, and love." A portion of the paper wrapping in which it was posted to Dr. Johnston and which Whitman himself addressed has been preserved. Only one other copy of this edition is known to have been inscribed by Whitman, and that, which was sent to J. W. Wallace, of Bolton, is now privately owned. They were probably the last two books ever inscribed by Whitman. 
Another copy.

One of the ordinary edition of the preceding, bound in dark green cloth, lettering in gilt on backstrip. Contains a letter from J. W. Wallace to Dr. Johnston, dated 16 April, 1914, which mentions a proposed new book by Johnston- "Walt Whitman Calendar."

Another copy.

A later issue, bound in stiff green paper covers, lacking date at foot of title-page.

Complete prose works, [facsimile autograph on title-page]. Philadelphia: David McKay. 1892.

Re-bound for library use.

Walt Whitman in War-Time: familiar letters from the Capital. (In The Century Illustrated Monthly Magazine, N.S. Vol. 24, 1893.)

Calamus: a series of letters written during the years $1868-1880$ by Walt Whitman to a young friend (Peter Doyle); edited with an introduction by Richard Maurice Bucke, M.D., one of Whitman's literary executors. Boston: Laurens Maynard. 1897.

\section{Another copy.}

Inscription on fly-leaf: "With comradely greetings and happy memories of England, Samuel Maynard. Just before sailing Apr 17, 1899." Also contains brief chronology of Whitman's life in manuscript.

The Wound Dresser: a series of letters written from the hospitals in Washington during the War of the Rebellion; edited by Richard Maurice Bucke, M.D., one of Whitman's literary executors. Boston: Small, Maynard and Company; London: G. P. Putnam's Sons. 1898.

Leaves of Grass; including Sands at Seventy, Good-Bye My Fancy, Old Age Echoes, and A Backward Glance O'er Travel'd Roads. Boston: Small, Maynard and Company; London: G. P. Putnam's Sons. 1898.

Copy presented by four Bolton lovers of Whitman ("Boys of the College") to Dhoondi Raj, and signed by them.

Notes and Fragments Left by Walt Whitman, and now edited by Dr. Richard Maurice Bucke, one of his literary executors. Printed for private distribution only. 1899.

No. 42 of the limited edition of two hundred and twenty-five copies, signed by Dr. Bucke.

Leaves of Grass; [edited by David McKay]; including a facsimile autobiography, variorum readings of the poems, and a department of "Gathered leaves." Philadelphia: David McKay. [1900].

Complete Prose Works: Specimen Days and Collect, November Boughs, and GoodBye My Fancy. Boston: Small, Maynard and Company. 1901.

The Complete Writings of Walt Whitman; issued under the editorial supervision of his literary executors, Richard Maurice Bucke, Thomas B. Harned, and Horace L. Traubel; with additional bibliographical and critical material prepared by Oscar Lovell Triggs, Ph.D. The Book-Lover's Camden Edition. New York and London: G. P. Putnam's Sons, The Knickerbocker Press. 1902. 10 vols. 
An American Primer. (In The Atlantic Monthly, Vol. 93. 1904.) pp. 460-470.

Originally written about $1856-7$, but not published. Prepared for publication by Horace Traubel.

Memories of President Lincoln. [Issued in 1904 as the August number of "The Bibelot: a reprint of poetry and prose for book-lovers, chosen in part from scarce editions and sources not generally known"]. Portland (Maine): Thomas B. Mosher. 1904.

Sent to Dr. Johnston by Horace Traubel.

Specimen Days in America. London: George Routledge \& Sons, Ltd. The New Universal Library. [1906].

"Échoes de la vieillesse (additions posthumes); poèmes traduits par Léon Bazalgette." (In La Revue des Lettres et des Arts, Juin, 1909.) pp. 358-363.

This copy of "La Revue des Lettres et des Arts" was sent to Dr. Johnston by Léon Bazalgette.

Feuilles d'herbe; traduction intégrale d'après l'édition définitive, par Léon Bazalgette; avec deux portraits de l'auteur. Paris: Mercure de France. 1909.

Inscribed by the author: "To my dear friend Dr. John Johnston, this labour of love, with which are involved for me years of joy and hard struggle. L. Bazalgette."

Leaves of Grass. The People's Library. London and New York: Cassell and Company. 1909.

Attached to the inside front cover is a copy of a single-verse poem found amongst Whitman's papers, beginning: "Full of wickedness I . .."

Leaves of Grass (1) and Democratic Vistas; [with an introduction by Horace Traubel]. Everyman's Library. London: F. M. Dent and Sons. [1912].

This work was originally planned in two volumes, but, owing to copyright, the poems included only those written up to 1871 , and so the projected second volume was not published. In 1947 the "Everyman's Library" issued a volume which contains all the poems that Whitman wrote and published in the "Leaves of Grass" series up to the time of his death, in 1892 .

Drum-Taps. London: Chatto and Windus. 1915.

Le panseur de plaies: poèmes, lettres et fragments de Walt Whitman sur la guerre; (traduction inédite [par Léon Bazalgette]); avec deux portraits hors texte du poète. [Paris]: Revue Littéraire des Primaires "Les Humbles." 1917. Bibliography.

Inscribed on title-page by the translator, L. Bazalgette: "To Dr. John Johnston, from his grateful old friend, L.B. Jan. '18." 


\section{SPECIMENS OF WHITMAN'S HANDWRITING IN ADDITION TO THOSE RECORDED UNDER \\ "LETTERS AND CARDS"}

Newspaper covers to J. W. Wallace:

(a) signed: "from Walt Whitman U S America"

(b) signed: "Walt Whitman Camden New Jersey U S America"

On a single sheet of paper, in blue pencil:

"Six copies pocket bound morocco gilt L of G for J.W.W. [J. W. Wallace], W. A. Ferguson, Sam Hodgkinson, W. M. Law, Rev. S. Thompson, Wm. Pimblett, Fred Nightingale. Paid."

All the people named were members of the "Eagle Street College," to whom Whitman supplied copies of the 1889 pocket-book edition of "Leaves of Grass," for which J. W. Wallace had forwarded 30 dollars, as is shown on the reverse.

Book inscriptions:

Leaves of Grass. 1855: "For Dr. Johnston"

1871: “J. Johnston from Walt Whitman July 16, '90."

1876: autograph on title page.

1876: autograph on title page Also, on a portion of the paper in which the book was delivered, Whitman wrote: "Leaves of Grass. Edition 1876, bound in Italian boards and white leather-autograph-two portraits from life-perfect copy- $\$ 5$."

1889: Autograph on title page and following inscription on fly-leaf: "Dr. Johnston in England, from his friend the author in America."

1891-2: "Dr. J. Johnston, Bolton, England, f'm the author, with best wishes, remembrance, and love." Also a portion of the wrapper which was addressed by Whitman.

Complete Poems and Prose. 1888: Autograph on first page of "Leaves of Grass." As a Strong Bird on Pinions Free. 1872: "J. Johnston from Walt Whitman July 16 '90."

Goodbye My Fancy. 1891: "Fred Wild from his friend the author Oct. 21, 1891."

Passage to India. 1871: "J. Johnston from Walt Whitman July 16 '90."

Two Rivulets. 1876: Portrait signed by Whitman. Enclosed is the wrapper which is inscribed: "Centennial edition-Two vols: Leaves of Grass \& Two Rivulets, bound in half leather and Italian card, containing Autograph, Portraits (three from life), Personal Memoranda of the War, 'Democratic Vistas', \&c. \&c."

"A Present to Dr. Johnston thro' kindness of J. W. Wallace (f'm America)."

In Burroughs (John), Notes on Walt Whitman, as poet and person. 2nd edition. [with additional notes, improvements, later statistics, etc.: the original text 
(at Washington, D.C.) in 1867-the "Supplementary Notes" p. 109 five years afterward]. 1871.

The bracketed words in the title were inscribed on the title page by Whitman, who presented this copy to Dr. Johnston with this inscription: "J. Johnston from W.W., July, 16 '90."

In Ingersoll (Robert G.), Liberty in Literature . . . [1890].

Sent by Whitman to Dr. Johnston. The wrapper, addressed to Dr. Johnston by Whitman himself, is preserved in the book.

In Traubel (H. L.), editor. Camden's Compliment to Walt Whitman. 1889.

Inscribed: “J. Johnston from Walt Whitman July 17 '90." Also, on p. 53, Whitman wrote: "This is the letter of R. S. [Rudolf Schmidt] referred to by me when Dr. J ask'd ab't the photo in Mickle St."

\section{LETTERS AND CARDS}

Original autograph letters signed by Walt Whitman to:

Bessie and Isabella Ford, London,

(a) letter, in original cover, August 3, 1885.

Whitman thanks the Misses Ford and Edward Carpenter for an "affectionate generous gift of $£ 50$. It has come very opportunely."

(b) postcards, May 28, 1884 and August 11, 1885.

Thomas B. Harned,

letter, February 15, 1889. Pencilled draft.

This is a draft of a message which Whitman inscribed in Harned's copy of the 1888 "big book."

Facsimiles of original autograph letters:

J. Johnston, November 1, 1890; June 27, 1891.

J. W. Wallace, May 28, 1891.

Copies of letters:

Copies of letters and postcards from Walt Whitman to J. Johnston and J. W. Wallace, May 29, 1887 to Feb. 6, 1892. Typescript.

Most of these letters and cards were reproduced in "Visits to Walt Whitman," by Johnston and Wallace. The majority of the originals were presented, by the recipients, to the Library of Congress, in 1924, the official acknowledgement of which is in our collection.

Letters from Whitman's literary executors:

H. L. Traubel to J. W. Wallace.

Several hundred letters covering the period 1891-1919.

H. L. Traubel to J. Johnston.

A few letters of various dates.

R. M. Bucke to J. W. Wallace.

Several letters from 1890-1901.

T. B. Harned to J. W. Wallace.

Several letters from 1918-1921. 
Letters from Anne Montgomerie Traubel.

Mrs. Traubel's correspondence covers the period 1891-1953. It started with J. W. Wallace, and continued, after his death, with his adopted daughter, Mrs. M. Whiteside.

Other letters to J. W. Wallace having a Whitman interest, from:

Frank and Mildred Bain

Dr. Clara Barrus

L. Bazalgette

H. B. Binns

Robert Blatchford

John Burroughs

Edward Carpenter

Jean Catel

Ernest Dowden

Henry Buxton Forman

Grace Frend (née Gilchrist)

F. Warren Fritzinger
Bruce and Katherine Glasier

J. Keir Hardie

Will Hayes

J. H. Johnston

J. W. Lloyd

J. Ramsay MacDonald

Ernest Rhys

"AE" (George Russell)

Henry Saunders

Mrs. Harriet Sprague

John Addington Symonds

Stanley Unwin

\section{RELICS AND MEMENTOS}

Canary—stuffed and mounted.

"This bird, which was the subject of Whitman's lines 'My Canary Bird' died shortly after my visit, and Mrs. Davis had it stuffed. It was brought to Bolton by Dr. Bucke, in 1891, and presented to Mr. Wallace." J. Johnston, "Visits to Walt Whitman," pp. 60-61.

Walt Whitman's cup and saucer, presented to J. W. Wallace.

Head of Walt Whitman. Plaque by Sidney Morse, 1902, inscribed "A memory of '87." 15 in. x 12 in.

Water colour "Rivington Lakes," signed A. H. Cooper, 1891. 13/1/2 in. x 9 in.

On June 19, $1891 \mathrm{~J}$. W. Wallace sent to Walt Whitman four water colour sketches of Rivington, by A. H. Cooper. In a postscript he wrote "If Traubel fancies any of them I shall be glad to arrange with Cooper for a painting. I wanted to send something and could think of nothing better."

This picture of the lakes at Rivington, near Bolton, was commissioned by the members of the Bolton Whitman Fellowship, for presentation to Horace and Anne Traubel in 1892. The artist, Alfred Heaton Cooper, then resident in Bolton, was a friend of Johnston and Wallace, and he later gained fame for his Lakeland paintings and book illustrations. In 1948 Mrs. Anne Traubel presented it to the Bolton Public Libraries as being of special interest to the Bolton Whitman Fellowship.

Loving cup, presented by J. H. Johnston.

$6^{1 / 2}$ in. high, $4^{1 / 2}$ in. diameter, silver mounted rim, inscribed "The College Loving Cup. 'Something for a token' From J. H. Johnston, New York, 21 st July 1894.” The donor of the cup visited the "College" later in 1894. 


\section{PAINTINGS, PHOTOGRAPHS, etc.}

Walt Whitman:

1. Portrait in oils by Sidney Morse.

"And that," I said, "is another oil painting of yourself?"

"Yes," he said, "do you like it?"

"I do," I replied hesitatingly.

"Then you may take it with you if you like, I don't care for it," he said. "It was done several years ago by Sidney Morse, but I don't think it is satisfactory."

J. Johnston, "Visits to Walt Whitman," p. 54.

2. Photographic copy of a photograph, original inscribed by Whitman "Harry \& Kitty \& Walt Whitman, May 1879."

3. Photograph copy of original photograph - no date- but approximately at the same time as item 2 .

4. Photographic copy of photograph presented by Whitman to J. W. Wallace, inscribed "Walt Whitman in 1890."

5. Several photographic copies of paintings and early photographs.

6. Postcard reproductions of Whitman's house, plaque on his house, and tomb.

7. Photograph by Henry Saunders of Walt Whitman's house, 1911. Signed by seven members of the Toronto Whitman Fellowship Meeting, May 30, 1925.

8. Portrait of Walt Whitman by J. W. Alexander, reproduced in "Munsey's Magazine."

9. Two photographs of Walt Whitman's memorial at Bon Echo, one showing group taken 25 August, 1920, after ceremony to celebrate the completion of the inscription.

10. Masterpiece Library. Walt Whitman, born 1819, died 1892. Our poet's corner, No. 23. Coloured plate. 1895.

Frank Bain: Photograph dated 1909.

Mildred Bain: Photograph dated 1910.

R. M. Bucke: Photograph of R. M. Bucke and family. Sept., 1899.

Photograph of R. M. Bucke and J. W. Wallace. 25 August, 1891.

John Burroughs:

1. Photograph of John Burroughs holding chipmunk. 1901.

2. Photograph of John Burroughs. 1918-taken in Chicago.

3. Photograph of J. Burroughs and Clara Barrus "on the stoop," Woodchuck Lodge, 29 Sept., 1920. 
4. Photograph of John Burroughs at his open-air cooking stove.

5. Photograph—indoors—of John Burroughs and Clara Barrus.

6. Photographic reproduction of portrait by Orlando Rouland.

7. Postcard reproductions of John Burroughs and his house.

Edward Carpenter: Signed photograph 1912.

Bruce Glasier: Undated photograph.

Katherine Glasier: Two photographs.

Thomas B. Harned: Undated photograph.

Robert Ingersoll: Undated photograph.

William Ingram:

1. Printed Photograph.

2. Photograph with J. W. Wallace and Miss Ingram. (On the occasion of Ingram's visit to Bolton.)

3. Photograph of Ingram's home in New York.

John Johnston: Large framed photograph.

J. W. Lloyd: Autographed photograph.

Daniel Longaker: Photograph signed by both Longaker and Horace Traubel, Sept., 1892. (Daniel Longaker was Whitman's medical adviser.)

Henry Saunders: Two photographs—one signed, Oct. 20, 1913.

Helen Saunders: Two undated photographs.

Henry and Helen Saunders: Undated photograph.

Anne Montgomerie Traubel: Three photographs-various years.

Horace L. Traubel:

1. Photograph of Horace L. Traubel, inscribed "To J. W. Wallace 1904." "For love forever-Horace Traubel."

2. Photograph of Horace L. Traubel, inscribed "To you, Wallace, love, 1897. Traubel."

3. Photograph of Horace L. Traubel, inscribed "To Wallace. Memories \& love Traubel America 1895."

4. Photograph of Horace L. Traubel, inscribed "Yours dear Wallace for keeps Traubel 1897."

5. Signed photograph, 1905. "In the office."

6. Snapshot album entitled "Pictures of a trip to Peermont, August, 1906." Various photographs of the Traubel family. 
J. W. Wallace: Numerous individual and group photographs, amongst them:

1. Photograph showing him in the room at "Eagle Street College."

2. Photograph at desk in cottage at Anderton.

3. Photograph with R. M. Bucke, August 25, 1891.

4. Photograph with William Ingram and Miss Ingram.

5. Photograph of Wallace's grave in Tonge Cemetery, Bolton.

6. Large framed photograph.

Eagle Street College:

Group photographs dated 1896, 1899, 1900, 1903, 1905, 1908, 1913, 1916 (2 groups.)

Eight undated group photographs.

Photograph of interior of "Eagle Street College."

\section{EAGLE STREET COLLEGE}

Proceedings, References, etc.

Whitman Birthday Celebrations.

Reports for 1893, 1901, 1904-1908, 1910, 1911, 1913.

The report for 1893 is in manuscript; the others are reprinted from the "Annandale Observer."

Report of meeting held 24 August, 1891: "The College farewell to Dr. Bucke and J. W. Wallace." MS.

This meeting took place at the conclusion of Dr. R. M. Bucke's visit to Bolton and on the eve of J. W. Wallace's visit to Whitman. Edward Carpenter was among those present.

Report of meeting held 30 March, 1892: "Walt Whitman's funeral." MS.

Hawkins (Walt T.). Paper read at the Birthday Celebrations. 1912. MS.

Hawkins (Walt T.). Poems read at the Birthday Celebrations. 1906, 1907, 1910.

Reprinted from the "College" Whitman Birthday Celebrations reports for the same years.

Johnston (John). A college song, sung at the Eagle Street College, April 10, 1891. MS.

Johnston (John). The Eagle Street College nursery rhyme. April 28, 1890.

Johnston (John). Song: “The Masther" [J. W. Wallace] of Eagle Street College. April 29, 1889. MS.

lege." April 29, 1889.

The author, in marginal notes, has identified the members of the Group referred to in the various verses of the song. 
Johnston, John (as subject). A birthday song dedicated to the Doctor [J. Johnston], December 8, 1890. MS.

Wallace (James William).

Address delivered on Whitman Day, May 31, 1907. MS.

Address delivered on Whitman Day, May 31, 1923. MS.

Address to "The College," January 20, 1890. Typescript.

The "Calamus" poems in "Leaves of Grass": address in Bolton on Whitman's birthday, May 31, 1920. Typescript.

Copy of a letter to R. K. Greenhalgh for reading before a meeting of "The College," December 3, 1890. MS.

In celebration of the anniversary of Walt Whitman's birthday, May 31, 1819: address ... May 30, 1925, subject: "If Walt Whitman came to Walker Fold" [Bolton]. Typescript.

Manuscript notes, written May 30, 1888, for delivery at the "Eagle Street College."

A message to the "Eagle Street College," January 6, 1893. MS.

A rejoinder; [being a reply to criticisms of a paper read by Wallace to the "College," October 1, 1890]. MS.

Wallace, James William (as subject).

The Boys of the Eagle Street College to the master thereof, donatio amoris causa, dated August 10, 1889.

Manuscript, recording in legal phraseology, the gift of a writing desk to J. W. Wallace, on his 36th birthday, by nine members of the "College," all of whose signatures are affixed.

Leather bound illuminated address presented to J. W. Wallace, August 11, 1889 , by nine members of the "College," of all whose signatures are affixed.

Allen (Lily A.). "January: a month of memories." (In The Epoch, Vol. XXIX, No. 1, January 1927.) pp. 6-9.

Article dealing with James Allen and J. W. Wallace.

Eccles (Caroline A.). "Farewell and Godspeed! J. W. Wallace." (In The Epoch, Vol. XXVIII. No. 3, March, 1926.) pp. 58-60.

Eccles (Caroline A.). Fames William Wallace, an English Comrade of Walt Whitman: A Memoir. London: C. W. Daniel Company, Ltd. [1937].

Walt Whitman: a paper read to "The College." Typescript.

Author and date not stated.

Wightman (R.). Paper on Walt Whitman read to "The College," May 31, 1918. Typescript. 


\section{Eagle Street College.}

Binns (H. B.). A Life of Walt Whitman. 1905.

In the preface the author acknowledges his indebtedness to J. Johnston and J. W. Wallace of the "Bolton group."

Blodgett (H.). Walt Whitman in England. 1934.

Chap. XII, "Carpenter, Ellis, and the 'Bolton College'." 